\title{
基于教育游戏的小学数学教学设计研究
}

任正英

甘肃省兰州市永登县武胜驿镇聂家湾小学

DOI:10.32629/jief.v2i5.1489

[摘 要] 游戏教育是一种非常具有乐趣性的教育方式, 可以调动学生的学习积极性。在小学数学教学中运用游戏教育方式, 可以提高课堂效 率, 达到好的教学目的。本文就针对游戏教学在小学数学教学中的意义进行阐述, 并且说明在小学数学教学当中应用游戏教学的方法, 以供 大家参考。

[关键词] 游戏教育; 小学数学教学; 应用方法

中图分类号: G623.5 文献标识码: A

随着新课程的不断改进, 各个学科之间都在进行课程的改革与创新, 传统的教学方法很难再适应社会的发展要求, 各个学科都在进行着教育 改革和实验, 这一点在小学数学教学当中体现地尤其明显。小学数学教 学当中现在广泛应用了游戏教学这一新的教学方法, 因为游戏教学其本 身的趣味性能够调动学生的学习积极性, 能够唤醒学生对于美好事物的 向往和回忆。通过游戏教学方法的渗透, 学生不仅能够对数学学习产生 兴趣, 还能发展学生的情商, 为学生未来的发展奠定坚实的基础与厚实 的根基。通过引入游戏教学的方法, 小学数学课堂变得不再是那么枯燥 乏味, 而是充满了乐趣与情趣, 学生能够乐在其中而流连忘返, 愿意自 发地去探寻数学学习的本质, 这样也是教学的目的所在。教学最重要的 目的是能够唤醒学生的童真, 学生的心智因此而得到打开。下面我们就 来看看游戏教学在小学数学教学中的意义所在, 并且提出合理的应用游 戏教学的方法。

\section{1 游戏教育在小学数学教学中的意义}

1.1 提高学生的学习兴趣

我们都知道学生处于小学阶段都比较活泼贪玩, 而数学教学本身因 为其抽象性, 令很多学生望而却步。学生更需要的是一种具有乐趣性的 教学模式, 来满足其好奇心和活泼好动的性格, 而在小学数学教学当中 运用游戏教学, 可以将游戏融入到教学当中去, 摆脱学生注意力分散的 现象, 让学生的整个注意力能够被吸引在课堂教学之中, 让学生的注意 力能够集中在课堂之中。学生在课堂听讲的时候容易思路中断, 这就需 要老师用外部的环境来影响学生, 通过游戏教学可以让学生的大脑始终 处于一种兴奋的状态, 让他们对一些教学活动有自己的深刻感知和认识, 愿意自发地去学习一些数学知识, 这样就达到了教学的目的。

1.2 可以满足不同层次学生的学习需要

在一个年级当中, 学生的学习水平和认知能力都有所不同, 传统的 教学模式很难兼顾到每个学生的实际情况, 这样往往是学习能力较差的 学生渐渐地对于学习数学产生了畏惧之感, 久而久之数学成为了他们学 习的薄弱环节。而通过游戏教学的方式, 可以极大地满足不同阶段的学 生学习需要, 通过一些有趣味性的游戏, 可以调动学生的团队协作能力, 也可以使学生的学习积极性得到提高, 学生不仅仅是在学习一些冷冰冰 的数学公式, 也有一些其他的做人做事方面的技巧, 学生也都能通过游 戏教育得到学习, 学生的各个方面都因为游戏教学而得到发展和提高。

2 教育游戏在小学数学教学中的应用方法

2.1 改变教学模式, 提升教学内容的趣味性
教育游戏这一新的教学模式在小学数学教学中的应用, 可以是传统 教学模式的一大革新, 它完全摆脱了传统教学模式的种种束缚, 而用一 种全新的理念和方法来满足学生的求学需求。要将这一教学方法合理地 应用到小学数学教学当中, 就需要改变传统教学模式带给学生的种种束 缚, 适当增加数学知识的趣味性和游戏性, 这样才有助于学生的听讲和 课堂效率的提高。例如, 老师在讲解分类分组的教学内容的时候, 老师 可以让学生将自己家里的玩具带到课堂之中, 通过分类的方法将玩具分 成几种不同的类别, 让学生明白分类分组的意义。通过游戏玩具的教学 模式, 学生的注意力被吸引在了课堂教学当中, 学生的学习兴趣得到大 幅度提高。

2.2 转变教学观念, 注重学生的主体地位

传统的教学模式一直在强调老师的重要性, 就是老师在课堂将教学 内容讲好, 学生自然会学习好, 成绩突飞猛进。其实在课堂教学当中最 重要的是学生的态度, 良好的课堂教学旨在提高学生的学习积极性, 让 学生能够自主地探讨问题, 解决问题。老师在课堂教学过程中需要给学 生一些自主发挥的时间, 让他们能够自主地探讨一些问题, 并且将问题 加以解决。例如, 老师在讲解三角形的几何图形的时候, 可以让学生通 过小组合作讨论的方式进行探讨学习, 将一些三角形的实体展示给学生, 让学生在合作和游戏过程中认识几何图形, 加深对几何图形的印象。

2.3 引入多媒体技术, 使游戏教学与多媒体技术相结合

当今科学技术发展迅猛, 很多游戏都通过软件的形式展示在学生面 前, 为了能够将游戏教学更好地融入到小学数学课堂教学之中, 作为老 师需要合理运用多媒体技术, 将一些小游戏通过多媒体技术加以展示到 学生的面前, 让学生获得视觉的感知, 并且因此而提升课堂的教学效率。 例如, 通过连连看这样的小游戏, 可以让学生在游戏操作的过程中体会 到几何图案的识别方法, 让他们对几何图案有清楚的认识和了解, 从而 达到数学教学的目的。

\section{[参考文献]}

[1]李道博.试分析小学数学游戏性教学策略的设计与应用 [J].科技 创新导报,2014,36:118-119.

[2]郑瑞丽. 面向问题解决能力培养小学数学教育游戏设计研究 [N]. 佳木斯职业学院学报,2014,08:221-223.

[3]胡珂.巧用数学游戏,成就精彩课堂一小学数学教学中有效游戏设 计的实践案例[J].亚太教育,2016,33:28. 